Millei, Z., Korkiamäki, R. \& Kaukko, M. (2019) 'Arctic Childhoods' and mobilized differences - - the mattering of skis and skates in 'nation-ed environments' (pp. 49-64). In Rautio, P. \& Stenvall, E. (Eds) Social, Material and Political Constructs of Arctic Childhoods: An Everyday Life Perspective. Springer. https://www.springer.com/gp/book/9789811331602

\title{
4. SKATES AND SKIS
}

\section{'Arctic Childhoods' and mobilized differences - the mattering of skis and skates in 'nation-ed environments'}

Zsuzsa Millei and Riikka Korkiamäki, University of Tampere, Finland

Mervi Kaukko, Monash University, Australia/University of Oulu, Finland

\begin{abstract}
Children inhabiting Finland inevitably live through cold and snowy winters. Accordingly, winter sports, like skating and skiing, are a standard or national component of curriculum in Finnish schools as well as an expected part of children's leisure time. Skis and skates form a taken for granted part of the 'nation-ed environment' of Finland with which people feel at home. All this is often new to children who arrive to live in Finland from warm countries. In this chapter, we dive into the worlds of skis and skates and newly arrived children. Our reading is about skis and skates encountering children who negotiate the socio-material and cultural world of Finland. To foreground how objects matter to children, we apply the idea of ethnopoetry. By constructing poems from our data produced in two research projects with recently arrived children in Finland, and placing those in dialogue with quotes from a Finnish storybook and our own memories, we show how skis and skates fit in with children, mobilize difference or challenge the taken for granted view of a nation. Through stories of skis and skates, the nation, Finnishness, and the Arctic become perceivable as part of ongoing everyday processes that newly arrived as well as Finnish-born children and adults coordinate, sustain, tolerate, reject, and naturalize in encountering the world.
\end{abstract}

\section{PRESET}

Breath-taking and snow-covered landscapes, Northern Lights, nearly two hundred thousand lakes and more than a thousand kilometres of shoreline. To save energy on their everyday journey, people living in the area of Finland invented skating five thousand years ago ${ }^{1}$ and travel over snow on skis for six thousand years. Nature dressed in white, frozen sheets of ice, cool air on face, skates, skis, poles, helmets and wool socks are part of the winter in Finland and children's everyday lives and mobilities. "Early winter snowfall is ... a sign - a promise - of many things cultural as well as natural" (Rautio and Jokinen, 2016, p. 36). Cold weather and winter sports in schools embrace children arriving to

\footnotetext{
1 http:/ / www.messagetoeagle.com/ice-skates-were-used-in-finland-5000-years-ago/ http:/ / www.npr.org/templates/story/story.php?storyId=18447880
} 
live in Finland from warm climates. In this chapter, we explore how skis and skates, and children participate in the socio-material and cultural world of Finland.

Studies that explore children's experiences who have recently arrived to Finland frequently interpret those within the frame offered by their official identification as migrants or refugees. This singular view disregards children's self-identifications and the multiple and fluid ways in which identities are constructed, negotiated and claimed in different situations. The two research projects from which we extract children's experiences in this chapter have also, initially, identified research participants based on their official status in Finland as migrants. In this paper, however, we try to move away from this categorical framing of their experiences. We do not wish to privilege their ethnicity or migrant status in our explorations nor understand their experiences as foreshadowed by belonging to these groups. Instead, we elaborate on those everyday situations in which children find themselves attributed with ethnicity, being approached or labelled as migrants by others, or in which they themselves claim an ethnicity or migrant status to mark their own difference. Working this way allows us to perceive ethnicity as it is mobilized, continuously constructed, contested and negotiated, rather than using ethnicity as a fixity to explain children's experiences with (Brubaker \& Cooper, 2000; Fox and Jones, 2013; Forsman and Hummelstedt-Djedou, 2014).

In this chapter, we specifically focus on how children negotiate their belonging to a new nation. Instead of citizenship status or claims to belonging to a historical nation bound by a unity of culture, we understand national belonging as taken-for-granted and habitual ways of being and acting in everyday life led in 'nation-ed environments' (Noble, 2002). In 'nation-ed environments,' objects, such as skis and skates, have important roles to play (Skey, 2011; Noble, 2002). Besides developing familiarity with and habitual ways of acting in a new environment, for children who arrive to Finland this also means engaging in a process whereby they produce a sense of being 'at home' - a kind of 'ontological security' (Noble, 2002, p. 54). This process also includes children understanding their experiences and claiming their identities in relation "to a larger social environment and its social relations and cultural categories" and materialities (Noble, 2002, p. 54). As part of the nation-ed environments of Finland, we explore how skis and skates differently matter to children and how they participate in producing sameness and difference. As Rautio and Jokinen (2016, p. 39) elaborate:

Most things arguably both matter and have meaning. Meaning is often the retrospectively assigned attribute to a practice that took place because it mattered. Meanings can be speculated or imposed by anyone, and mattering is only for those involved in the moment. Yet, mattering and meaning do not necessarily settle as a linear and/or causal connection in which mattering would always precede meaning.

To show how skis and skates matter, we focus our explorations on everyday life and different modalities of difference. By everyday life we refer to a domain of inquiry, it is "a place, not spatially or temporally circumscribed, but imperfectly delineated by the individuals who people it" and objects participate in it (Fox and Jones 2013, p. 396). The everyday is a productive term as it signals spaces, processes, socio-material environments and people populating those. 


\section{Creating poems from data}

Our drive to escape the 'scientific search for meanings' and capture the everyday matterings, has resulted in reconsidering narrative strategies while presenting data and analysis. Our attempt is linked to debates about the textual implications of representational practices that has led to experimenting with new configurations to present data, such as textual experiments, "disruptive"' texts, or poems (Gonick and Hladki, 2005, p. 287). Through these creatively generated insights, one can "escape from analytic perspectives that have become stereotyped and stale" (p. 13) and "reveal different facets of the data" (Coffey and Atkinson 1996, p.15). They can also involve a shift in the researcher's analytical ontology, moving from looking at the participants of the research to looking at the socio-material world alongside them where the researcher is also included (Edwards and Weller, 2012). However, as Atkinson (1990) states, these innovations need to be made responsibly and thoughtfully.

Following these experiments, we re-present data in a series of poems to open it up for multiple modalities and interpretations. In our poems, skis, skates and children emerge as characters in a story acting in emotionally charged environments. We re-present data from the two projects as symmetrical configurations, where both humans and non-humans are authors of their relations (Sørensen, 2013). In this way, data from the two projects and their (human and non-human) subjects communicate with each other. Working this way allows taken-for-granted symbolic systems and familiar material environments to mix in the moment that mattered to children in the constitution of everyday life, environment and self. Furthermore, we hope that this approach lets the data speak for itself, invite a range of interpretive responses, create open-ended and evocative connections, evoke the emotional dimensions of participants' and researchers' experiences, effect readers' emotions and intellect and reveal the social power of material objects (Sparkes, 2009; Haldrup, 2016).

Our method works similarly to ethnopoetry, research and writing techniques that depart from standard social scientific representational method of ethnographic data. Aitken (2014, p. 21), for instance, uses poetry in his study to "provide a parsimonious rendering of emotions that exceeds the text" by pushing the words to "reveal the emotional power of a conversation" to get to the "embodied power that resides in people and places" and objects. It is an attempt to represent the non-representable of a story, focusing on what matters to children and researchers.

Our "modestly playful" (Coffey and Atkinson 1996) implementation of ethnopoetry is inspired by an (I-)poem method, developed with the purpose of switching the position of a researcher in the analysis process from reading the data into listening to them (Gilligan et al., 2003; McLean et al., 1996; Brown and Gilligan, 1992). This is done through providing the data a possibility to be heard differently by re-creating data in a new format. However, while the idea of I-poems is to "trace how participants represent themselves through attention to first person statements" (Edwards and Weller 2012, p. 203), our creating of skate and ski poems is about foregrounding the non-human participants of skates and skis and downplaying the role of meaning making by children. By bringing skates and skis into a symmetrical positioning with children, we aim to shift the interpretative focus from our original 
research interest in people's words, toward everyday materials and the ways in which children and objects (skis and skates) 'be and become' together.

In practice, our idea was to pay detailed attention to the use of the terms 'skate' and 'ski' and not be "contained by the full structure of sentences" (Edwards and Weller, 2012, p. 205). We used our rich ethnographic data, consisting of research diaries, interviews and children's drawings, to create the poems through following three steps. First, we went through our research notes and transcribed interviews and identified phrases with skis, skates, related verbs and other pertinent words (such as helmet, stick, snowboard, falling, snow, cold). Second, we lifted the phrases out of the original data in the sequence that they occur and placing them in separate lines, like the lines of a poem, each skate or ski phrase in its own line. Third, we changed past tense into present and made slight changes with word orders, such as removing beginnings and ends of sentences if they were not about skates/skis.

This procedure helped us to identify skis and skates as social objects with their own biographies (Appadurai, 1986; Kopytoff, 1986), which we foreground in our reading of the poems. Skates and skis are "objects of knowledge" (Silverman 2015) - not only objects that people know about, but objects that also 'know' by storing knowledge - that travel through times and spaces, coming across people and (other) objects with their unique biographies and, hence, connect people and things from different times, places, cultures and positions. These connections may take place in concrete ways as people share objects and the knowledge they carry, or handle objects once created and treated by other people. But objects create connections also by their very existence as biographical, as they inevitably provoke imaginations, tell stories that people conjure and can recall, and animate their human cohabitants with "affects and emotions, feelings of remembrance, affection, appreciation and loss" (Haldrup, 2016, p. 52). With our poems and the subsequent reading of them, we are exalting the skates and skis to find out what kind of encounters with children they create, invite, mobilize and take part in, as they cross with children and the researchers' everyday lives in Finland.

As another strategy to promote multiple interpretations and avoid pressing rigid meaning into the data (see Rautio and Jokinen, 2016), we place quotes from a Finnish author Tove Jansson's storybook Moominland midwinter (1958) into dialogue with poems created from our data. By showing how the snow, skates and skis encounter the Moomins, we wish to spark possible interpretations and create room for emotional and embodied matterings to surface. Furthermore, poems and the Moomins mattered to us, the researchers writing this text, memories awoke that now accompany the poems. We feel that while these memories remain in the background, they are inseparable from our representational practice and thus need to be shared.

\section{A STORY OF SKIS AND SKATES}




\section{SKATING DAY}

Friday December 2nd is our school's joint outdoors day. Bus rides to the skating rink leave from schoolyard according to the class groups, and return to the same place. All students shall come to school at 9 am and go home at $1 \mathrm{pm}$.

School meals are provided as usual.

NB! During the skating day, everyone is responsible for his or her own equipment. Remember to label all your equipment. Helmets are required for all skaters. During the school skating day, we do not play ice hockey; please leave your sticks at home.

We spend all day outside; remember to dress accordingly!

There is equipment to borrow from the school on demand. Please let the teacher know beforehand.

Figure 1. Skating day announcement to students' homes.

As had been a tradition of the school for longer than anyone could remember, an 'ice skating day' was organized to mark the coming holiday season in the beginning of December. Each child and adult of the school was expected to participate - including the 19 boys of the preparatory classes ${ }^{2}$, between the ages of 13-17 years. These boys had arrived in the past year in Finland from the Middle East, Afghanistan and Russia. As part of her ethnography focusing on young migrants' social relationships, support networks and everyday lives in Finland, Riikka happened to be present at the school the week before the skating day, observing, taking notes, and talking to people. She had already become familiar with the school, its rooms and hallways, objects and items, routines and children breaking those, and its people: the boys and their teachers, other students, and school adults. She was not able to attend the skating event, but as it seemed to occupy everybody's minds and talks that week, she judged it was important. So she made notes about the forthcoming skating day: discussions concerning it, activities related to it, movements, bodies, gestures, places, spaces, mobile things and objects, constituting seven handwritten pages on skates and skating.

Meanwhile, in another town in Northern Finland, Lilith, a girl from Middle East, was thinking about her school experiences by drawing and talking to Mervi. The February day was one of the coldest of that winter. Temperature was almost 30 below zero in Celsius. Mervi, being interested in the experience of educational success of children with refugee background, gave open-ended instructions for this girl: Draw your school journey from the day you started school up to this moment, and mark anything that has been important to you. Lilith had come as a refugee to Finland four years ago. As the other 44 students interviewed after her, Lilith chose to share with Mervi a varying collection of

\footnotetext{
2 Preparatory education is a targeted program for recently arrived migrant students, aiming at providing them with sufficient level of Finnish or Swedish language and other necessary skills while studying in small groups before entering the mainstream education. This research was carried out with two groups participating in preparatory education. All the 19 children attending these groups were boys aged 13-17.
} 
critical events, significant people and objects as part of her school journey. However, unlike anybody else, this girl drew a green pair of skis in a central position of her drawing, and talked about their significance to Mervi.

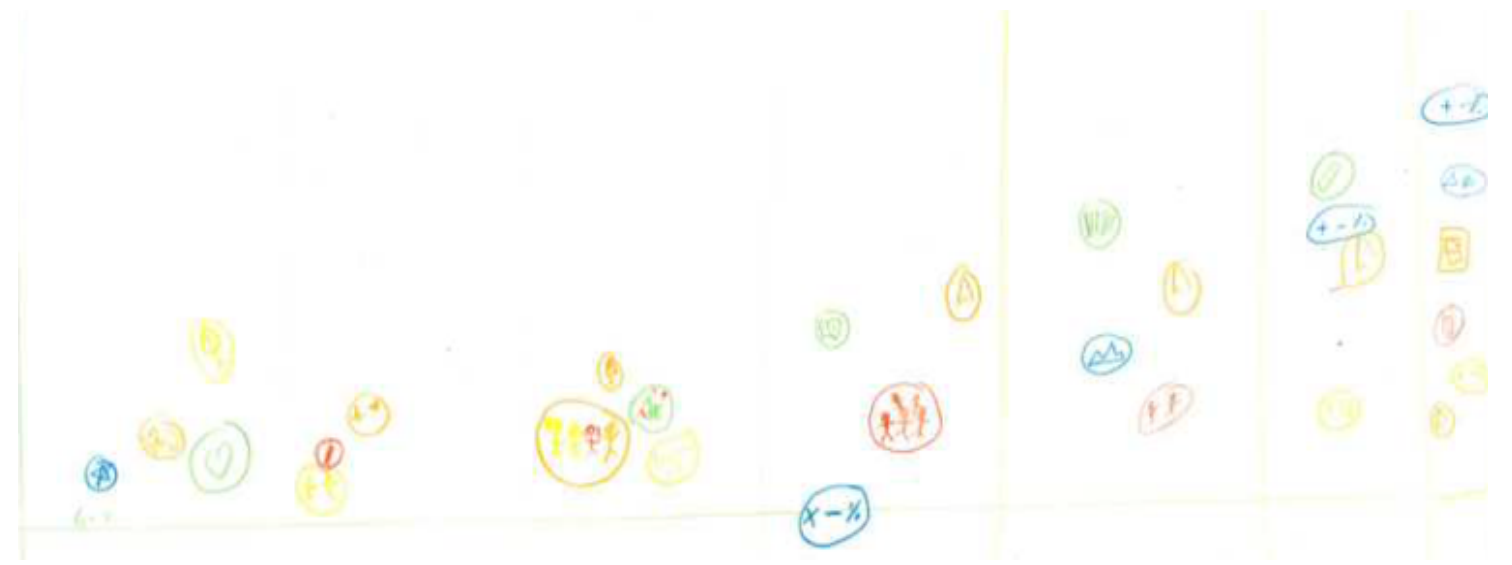

Figure 2. Lilith's drawing, representing significant events, important things and central persons during her school journey.

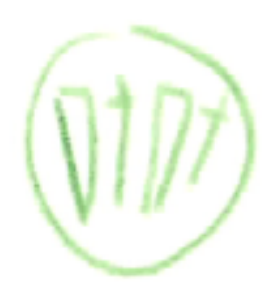

Figure 3. Detail of Lilith's drawing, representing a pair of green skis and ski poles. This detail can be found on the upper half of the picture, on the right hand side as the highest object of one of the school years, which are separated by vertical yellow lines.

\section{November 29: Emergence}

First scene: Classroom. The skates are not on stage yet. Teacher confronts the boys. ${ }^{3}$

\footnotetext{
3 The poems are created from the fieldnotes and interviews of the two studies. The poem on the left is from the study that Riikka conducted with the preparatory class boys, and the one in the middle is from Mervi's study with Lilith. The lines in italics are quotations from child participants extracted from the transcripts of Lilith's interview, or from Riikka's fieldnotes. All the other lines (not in italics) are from Mervi's and Riikka's field notes or other participants' words. The column on the right side of our poems represents the quotes from Moominland midwinter (Jansson 1958).
} 


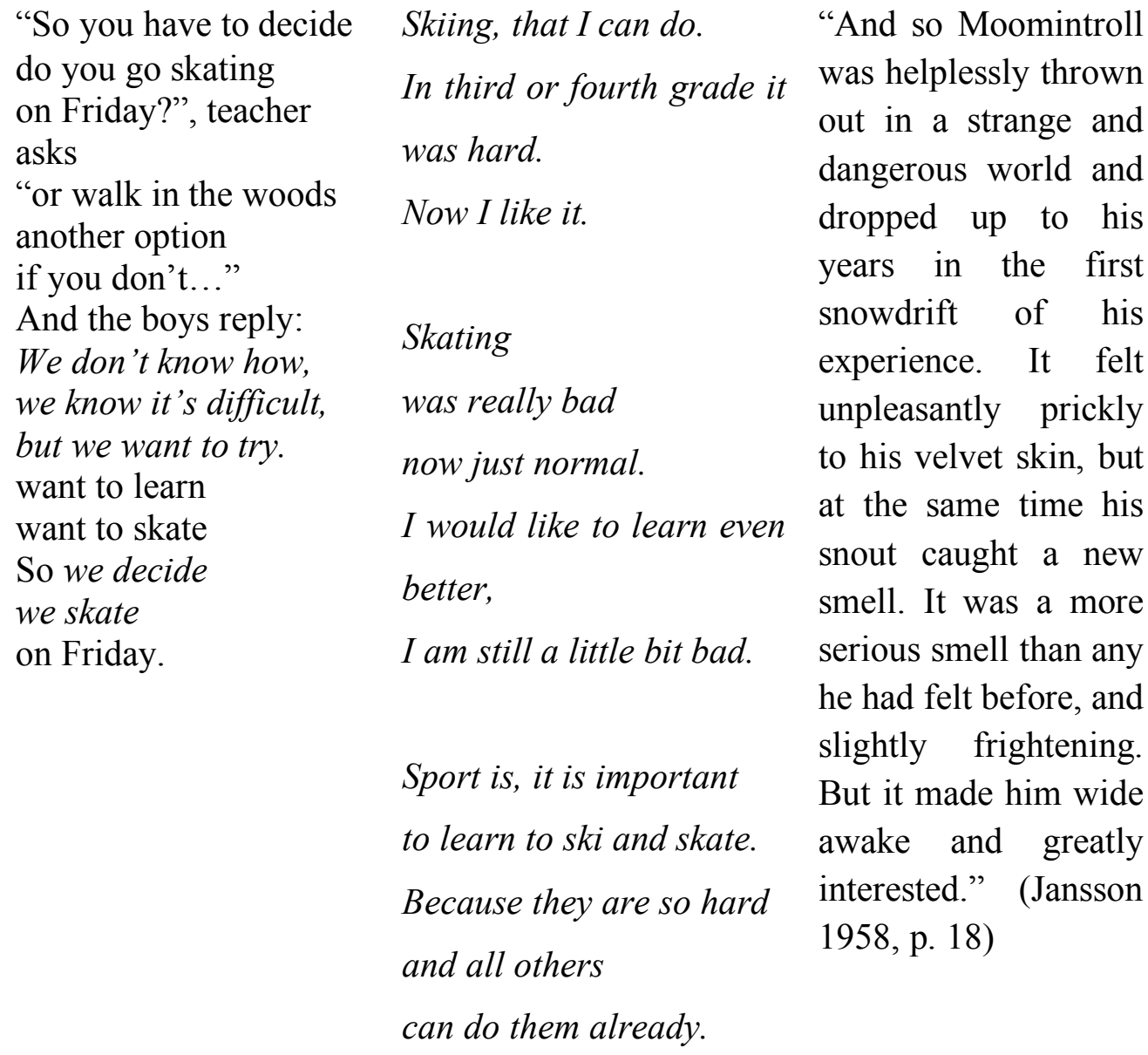

Like the nature dressed in white, skates and skis manifest emergence. For Lilith, the preparatory class boys as much as for the Moomins, skis, skates and winter mark the beginning of something new, a promise of something that is about to happen, something to be excited or anxious about. However, separations also emerge as the snow, skis and skates, carrying along their lived biographies, appear in the lives of children and the Moomins. Skates, skis, and arctic winter separate those who mingle with snow with confidence from those for whom it presents a 'serious smell'. At a first step, they bring out the helplessness from every child, as everyone is born as novice to skating, skiing and winter, regardless of whether living in a warm or cold climate or in a house with or without winter sport equipment. The snow is cold and uncomfortable on every bare skin, and the ice is slippery for everyone. However, mobilized by these 'knowledgeable objects', separations emerge based on when first and with what frequency the skis, skates and snow present themselves in one's life.

Also the white figure skates with pointy blades left the storage room of young Mervi's family house in the North of Finland infrequently. Winter sports days made an exception, on those days, skates travelled to school. They were too big to fit in a school bag, so they clung clumsily to a handlebar of a bike as Mervi cycled to school. Skates were just as clumsy on Mervi's feet. They made Mervi fall, causing the hard ice to take contact with her tailbone, skates slip out from under her or decided to get stuck, always acted against Mervi's intentions. Despite her "Arcticness", skates did not automatically co-operate with Mervi. Evolution had not shaped Mervi's feet to fit skates or developed her balance to twist on pirouettes. 
In Hungary, the snowy days have always found Zsuzsa in great excitement. Snowballs and wooden sleighs made the play with friends fun. Their biographies did not have a story about sport. Rolling hills invited children to roll and sled down in the snow but not without challenging them. As they grew in size, more and more falls and hurtful injuries expanded their biographies. Skis and skates had no experience of Zsuzsa's feet, it is only her daughter's feet they now know in the ice and snow of Finland.

Skates, skis and winter awaken, raise interest, provoke feelings of excitement, challenge, concern, worry, bring about frustration and self-doubt. As the excursion was announced to the preparatory class boys, skates approached them, the same way as they first presented themselves to Lilith, or the way the 'serious smell' presented itself to Moomintroll who was 'helplessly thrown out in a strange and dangerous world'.

\section{November 30: Teasing}

Second scene: Gym storage room. Skates, old and worn in different sizes are sitting on the shelves. Boys arrive with the teacher.

"Find the right skates" - and the teacher goes

to the skates.

Vladimir has skates of his own, of course.

Other boys stand by the door ready to run.

"Everybody in Finland has skates"- teacher says.

I want to have skates.

"Do you know how to skate, have you skated before?"

No but I can skate - Sadiq says and

lifts his chin up,

looks away then at Vladimir, who rolls his eyes and shakes his head.

Riikka has skates at home, three pairs in different sizes

"I could bring the skates, you can borrow them, if you'd like to skate?"

Yes!

Teacher hands skates to boys.

Boys look at each other

look at the skate,
So much

powdery snow

everywhere.

So cold it was.

She hated

every moment

of skiing but

persistent to learn.

She tried herself first

many times

without luck.

Then her parents

paid for a lesson
"Without knowing

a thing about it, at

that moment his

velvet skin decided

to start growing

woolier. It decided

to become, by and

by, a coat of fur for

winter use. That

would take some

time, but at least the

decision was made.

And that's always a

good thing."

(Jansson 1958, p.

18) 
grinning, pushing each other,

towards the skates.

Rashid goes to the skate shelf,

finds himself a pair.

Others take skates

from the teacher.

Azar puts a skate on the floor,

takes a football, plays with it.

"Put the ball away, try on the skates"

Azar leaves the room with no skates.

Hamasa grasps Azar's left-behind skates,

doesn't try them on,

stands by the door,

holds the skates,

waits while Behnam places

a skate on the floor next to his foot and

shrugs his shoulders:

This is good. Skate is just like a shoe-

and he leaves the room

with his skates.

Who has used these skates before?

The skates look old.

They smell bad.

The boys carry their skates through school halls.

Everyone has a pair.

In the classroom the skates are thrown to the back of the room.

Left there. and then

she could do it.

Now I like it. 
spaces change. Coming across the novice children in school or at a ski resort, hence, are only glimpses in the biographies of skates and skis. These short experiences do not foreclose longer relations with children.

The materiality of skis and skates are telling about their biographies. They become old or smelly. They carry memories, successes and failures. As such, they animate emotional and social life. Skates and skis may be inert, passively waiting for their encounter with humans. They may be lying in a pile against the school wall or behind the closed doors of a skiing resort, soon forgotten after the last snowfall in early spring. When traveling from one hall to the other, from instructor to novice, or when they are lifted, measured, dropped or left in corners, they become potential agitators with the power to make things happen. As they are worn again, they can make children fly through the powdery snow, 'so much of it', and empower them. And sometimes, they find themselves thrown to the back of the room, 'left there'.

\section{December 1: Curiosity}

Third scene: Classroom. Skates, the ones from the gym storage and the ones Riikka brought, are waiting.

Skates

hanging in the hallway

Students walk by

Brief glances

The skates

get no attention.

But when the boys arrive:

What is this?

Why are they here?

And later,

skates in the classroom,

in their bags

under the sink,

by the trash can.

Why are they here?

Every time when someone goes

to the sink or

to the trash,

they peak in the skate bag,

or kick the skates,

or say something

about the skates,

or the skating day.
Because in Finland

it is so cold and there is

so much winter.

So it is nice

to be able to snowboard

and stuff.

to go to Syöte with friends and

snowboard

with others.

"The winter
probably
peopled was
strange creatures
who acted
mysteriously and
freakishly."
(Jansson 1958, p.


"Leave the skates be.

They are just skates,

and you can use them tomorrow."

Skating is difficult.

I skated last year.

Hussain imitates skating, walks around with twisted ankles

I want to skate but I don't know how.

"Vladimir will teach you,

he is in our school exactly because

he can skate so well."

I don't skate,

I play hockey.

Can we play hockey?

"No, we skate"- teacher replies.

All the fuss around the skates.

Vladimir shakes his head, picks up the old skates,

turns them in his hands,

feels the blade

tosses them to the bench.

Hussain gets the old skates and

Sadiq the new ones,

he feels the blade

with his finger.

It's good-

and he looks at Vladimir

with a knowing look.

Skates and skis, ordinary to some and exceptional to others, visualize know-how and ignorance, invite sureties and insecurities, and raise confidence and confusion. They have the ability of being simultaneously right in place and out of place, while they wait patiently, return looks, elevate to the air, fall on the ground, touch the hand. Skates position the human-other in social and material worlds.

Skiing resorts and snow had been keen participants also in Riikka's whole life, but a snowboard had never properly met her. Snowboards had tempted her, approached her during her previous ski journeys, in sport equipment stores, or at friends' houses, but they have never properly encountered each other. Snowboards threatened Riikka, to throw her off, make her incompetent, and make her participate in a funny scene that they had caused. But the snowboards also called her to try. Carrying 
the old and the young, boys, girls, men and women, the snowboards slid and curved the slopes, moved elegantly and seamlessly through the snow and across the hills. With their looks they enticed her, each lured her with a different tactic. If unchosen, they seemed to ask: "Don't you want to be a part of this? Access the fun, be like the others - belong?"

In children's school life, skates and skis participate in many ways. They are walked by, glanced at, or fussed over, receive headshakes. They are kicked, felt and then tossed away, evaluated. The restful moments of skis and skates is disturbed by the brief glances they enjoyed from children with a knowhow or by the curiosity of others. Skates and skis stir up actions and feelings, and contract intimate bonds with children, invoke belonging for some and alienation in others. They invite, tempt, repel, act indifferent, disgust, energize, patronize and evoke feelings of lightness, aspirations or abandoned lives. Skates and skis, being present, matter differently to children.

\section{December 2: Differentiation}

Fourth scene: Classroom. The skating day morning. Skates are still waiting.

Skates in pile under the sink by the trash can.

Some glances, no one has touched the skates.

Vladimir's skates are on his desk and a helmet, but no stick allowed.

The skates look nice and new, they are huge, one can't avoid noticing them, but the boys say nothing. Yusuf slightly strokes Vladimir's skates.

Jawed takes Vladimir's helmet, puts it on goofing around. Others too want to try it on, try robbing the helmet, having fun, ran riot a bit.

When I was on fifth grade, "Now let's teach

\section{I learned}

how to snowboard.

I tried in fourth grade when

we went to

Syöte skiing centre.

I couldn't do it,

it didn't go well,

with snow

and all.

In fifth grade I took

snowboarding classes,
Moomin how to ski," he said. "I'd prefer not, thanks," Moomintroll

mumbled and shrank back a little. ... "The main thing's to keep cool, whatever happens", the Hemulen was saying encouragingly and already fastening the skis to Moomintroll's paws. (Jansson 1958, p. 102) 
"Put the helmet away it's not yours."

The helmet is placed in its place

on Vladimir's desk.

Boys in the lobby playing table soccer but no skates.

"Why are you here? Where are your skates?" I don't know.

Outside the students stand in groups, waiting for busses holding their skates running around Skates and helmets lying on the ground.

Vladimir at the center of action with his hockey gears in his team shirt, but no sticks allowed.

The boys come outside but no skates

Teacher guides them to stand in no-skates group.

"Where are your skates?"

I don't know

how to skate, we walk in the woods. There is a separate bus for non-skaters.

No-skaters stand by the wall.

Sadiq comes outside, holds his skates.

"Over there" - teacher points to no-skates group, but

I have skates.

"Oh can you skate?"

Yes! then I could do it!

Except I forgot to stop.

I stopped so that I

fell down

on purpose.

With snow

I am not very good

but hey,

I am a (her nationality)! 
He goes with the $8^{\text {th }}$ graders

who have skates but

keeps glancing

at no-skates group.

Boys turn to look as

Sadiq takes his skates

towards the $8^{\text {th }}$ grade skaters.

He stands close

to the $8^{\text {th }}$ grade group, but

not with them

the skates

in his lap.

Assistant teacher

brings Sadiq a helmet.

Skates differentiate. Old, used skates and the brand new ones hang in children's hands or enjoy a warm lap, or just rest on the ground. Helmets relish the love of some and suffer the indifference of others. Old skates often have memories of novice skaters - those feet that hesitate. Nice skates may remember experts, having only felt practiced feet. However, there are also brand new skates that chisel novice feet. Snowboards at ski resorts scare or desire a stroke from children or just shyly look away. Snowboards may remember the expert to whom they gave a speedy slide down the slope but who fell down at the end just like a novice skier. Skis, skates and snowboards meet differently each child.

Skates connect. They bring together different children on the ice rink, in the same bus or at the schoolyard. Skates travel in their bags, helmets encase children's heads or just wait on the ground. Sticks cannot attend, obeying the rule of 'no sticks allowed'. And then there are those skates that suffer from abandonment, wait lonely on the classroom desk or the snowboards that like to tease some and trip others. Skis, skates and snowboards connect and differentiate between children as they weave their biographies through encountering, connecting, separating or differentiating them.

\section{December 3: The day after}

Fifth scene: Classroom. The day after the skating day. The skates in bags and sitting on shelves.

Skates are still

Lilith draws the skis.

"Everything that had

under the sink

in the corner of classroom.

once moved had 


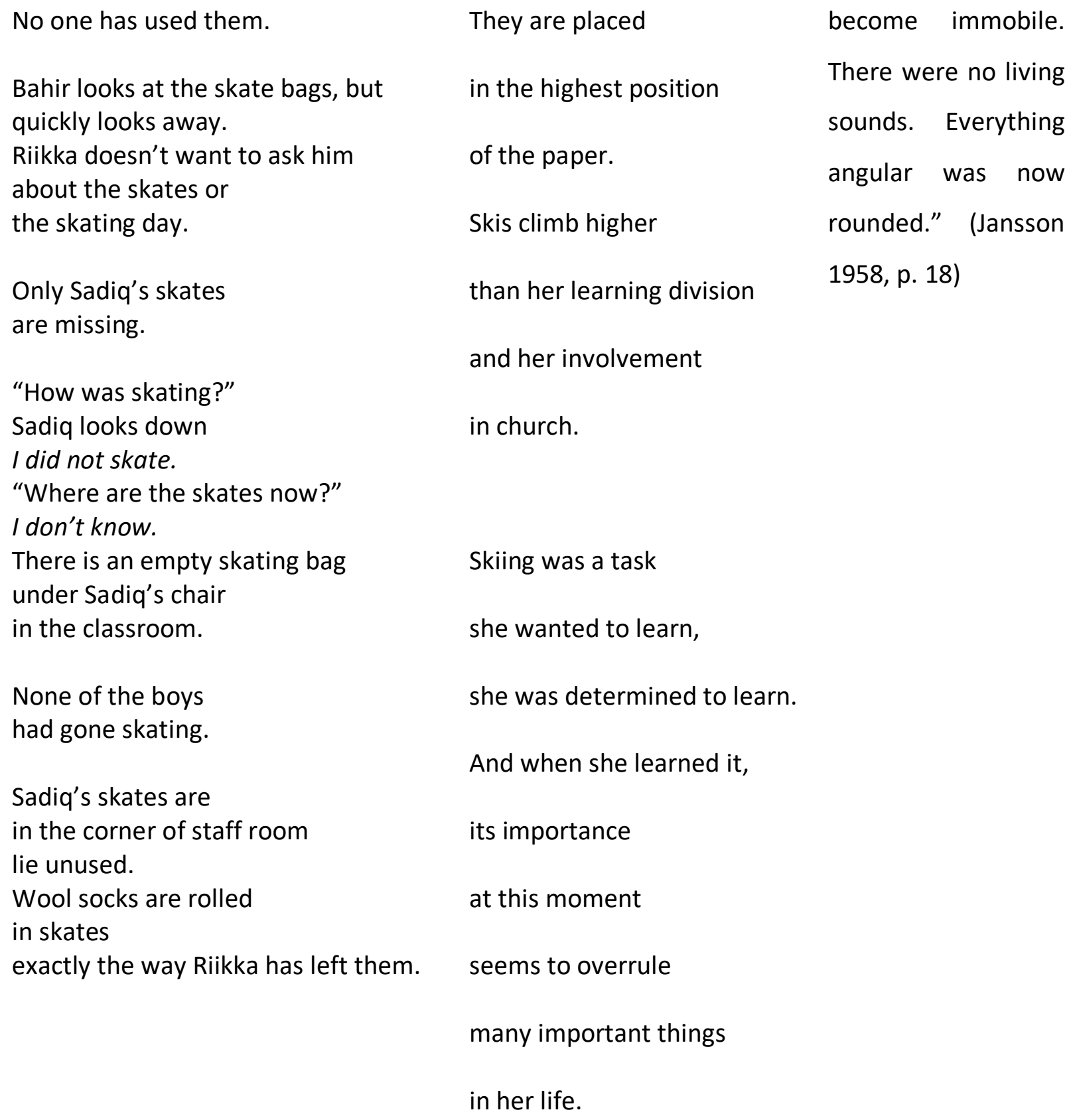

Winter keeps nature motionless, sleeping. But in winter, skis and skates speed up travellers' mobility. Skis and skates make some children mobile while others immobile. Boats, trucks, cars or planes moved the children through many locations before arriving to Finland. When skis and skates meet children, they can stop them in their tracks.

Skates, skis and helmets also have periods of immobility in their biographies. They are inert, unused, or return to their immobility after being placed back on the hook. Objects and bodies, stopping and going, create choreographies in their shared biographies. 
Listen, winter creatures, who have sneaked the sun away,

Who are hiding in the dark and making all the valley grey:

I am utterly alone, and I am tired to the bone,

And I'm sick enough of snowdrifts just to lay me down and groan.

I want my blue verandah and the glitter of the sea

And I tell you one and all that your winter's not for me!

(Jansson 1958, p. 46)

The skating day is over. The skates teased the boys, they invoked curiosity and gathered new trajectories in their biographies. Now, the skates are hanging limply on hooks. Different presences emerge for the skates and for the children. For Lilith, the green skis kept teasing her so successfully that at the end, the air, snow, cold and ice became indistinguishable from her body. Skis and Lilith emerged anew in the Arctic environment.

\section{SKATES, SKIS AND 'NATION-ED ENVIRONMENTS'}

The poetic reconstructions of our data from the two studies and its juxta-positioning with quotes from Moomin's experiences and our memories helped us to resist easy and conventional meanings. We used the power of intertextuality, pause and silence in our attempt to articulate more than what is sayable, to evoke emotions and mattering in everyday life. In our reading, we considered together the data, quotes and memories, and foregrounded the 'experiences' and 'actions' of skis and skates as equal participants in events, and as carrying social power in their encounters with children. Skis and skates acted as gatekeepers prohibiting less experienced and less willing children's bodies from entering with them in to the snowy and icy environment. Skates and skis connected some and differentiated others as less daring, willing, practiced or talented based on children's expertise and histories with them, or the lack of those. Growing up in cold places with lots of snow and ice and being surrounded by skis and skates compose important aspects of the Finnish national culture and imaginary, but do not routinely make children experts. On ski and skate occasions in schools, skates and skis divide children - novice and experts, sometimes on national or cultural lines, but that is not necessarily the case.

Like the biographies of travelling material objects, also a child's body "bears the traces of the places it had known. These traces are continually laid down in the body, sedimenting themselves there" (Casey, 2011, p. 688). A child's body can become attuned to climatic environments as she or he frequents places and uses objects, such as skis and skates. A child's place-world is "energized and transformed by the bodies that belong to it" (Casey, 2001, p. 688), including human bodies and nonhuman objects, animals, sun and wind, warm and cold, sand and snow, skis and skates, helmets and woollen socks. Through encountering these, children's bodies bear the places they have known lastingly. The icy or hot environments linger in children's bodies in the form of presence (Casey, 2001). Foregrounding objects - skis, skates, ice and snow - can help us show how objects and climates 
matter differently to different children and what presences they produce. Newly arrived children encounter the icy and cold place-world of Finland. Recalling lingering body memories, or creating new memories as they become subjected to this new environment, memories and new encounters produce belonging, exclusion, longing or concern. The embodied experiences of children in our poems tell about how some children made their bodies feel comfortable through repeated experiences with the Finnish environment and at other times became alienated by it.

To some, acquainting with skis and skates may produce a sense of 'ontological security' — "a familiarity with and confidence in the world as we know it" (Noble 2002, p. 54), or as we are becoming to know it. Skis and skates, snow and ice, and bodies come together in encounters, where "life is opened up to what is not yet determined or is to be determined ... what happens in an encounter is never completely foreclosed" (Anderson, 2014, p. 82). To Lilith, skis were part of her feeling at home in the North as much as part of her increasingly independent mobility, becoming equal with "all others who can do them already" in the winter she learned to know. The first encounter with skates made it hard for the boys to remain as regular others, they may have passed or may have been singled out. In the poems only hints of how they were becoming with skates were revealed.

In the new home countries of children and young people, dispositions to a new place and nation are rarely formed through abstract identifications with Finland as 'a country', a single identity of Finnishness as 'the national', or an ideal of an imaginary national citizen. Still the various ways in which migrants, children and adults, are being managed in and outside of school environments, the expectation is that identification with the nation can progress through transmissions of knowledge, norms and values. This is evident, for example, in the different leaflets produced for migrants to learn about the nation in different contexts, giving knowledge about what Finnish people like to eat or how they generally behave. This is also evident in the way in which Mervi made peace with skis and skates during her teacher training thinking that knowing how to ski and skate is a requirement to fulfil her duties as a teacher for Finnish (and new Finnish) children. Newly arrived children do not only encounter 'nation-ed environments' where skis and skates are part of an image of an ideal, traditional, real or active Finnish childhood, they also encounter it as a gathering of taken-for-granted and embodied practices of childhoods. This suggests that feeling at home or out of place in the North require socio-material and embodied experiences in which skis and skates can also participate (see Noble 2002, p. 54).

Finnishness, however, is not only about skates and skis. Childhoods can be experienced in multiple ways, the same way as skis and skates matter to children in different ways. At the end, nations are made real and come to matter to children and teachers through everyday socio-material encounters in local places (Brubaker, 2009; Skey, 2011), of which skis and skates compose only a small part. As Noble (2002, p. 61) further articulates:

our experience of and in the nation is primarily one whereby we live in nation-ed environments, where we experience nation as a kind of background to the conduct of everyday life ... construed largely through personal histories or aesthetic choices, the nation exists as a 'natural' cultural category or structure of experience. 
The nation, viewed from this perspective, is an ongoing process performed in everyday socio-material encounters in institutions. This process continuously reinvents itself by adjusting to changing circumstances of the socio-material, political and economic world. In the national 'structure of experience,' "relatively consistent sense of self, place, and time is (re)produced through routine habits, taken-for-granted symbolic systems and (un)familiar material environments (Skey, 2011, p. 35), such as the very skates, skis and snow and winter described in our poems. These 'nation-ed environments' and often 'unconscious' practices are encountered by newly arrived children as they lead their everyday lives. As they encounter national objects and environments, their capacity to experience themselves as belonging rest upon the "naturalization of a national experience through this background texturing" (Noble, 2002, p. 61). They coordinate, sustain and naturalize particular notions and experiences of the world, of living in Finland and living in the Arctic.

\section{The (non-conclusive) end}

We have built this chapter as a dialogue between four 'voices'. One 'voice', the most central, is presented as poems of skis, skates, winter and children. The second voice is that of the Moomins and their coming into terms with their world, Moominland, in midwinter. The authors sounded the third voice, the 'voice' that skis and skates speak in our readings of data. The fourth voice is ours as we, the three authors, remember and reflect on skis and skates encountering us. Skates, skis and snowboards participated differently in our lives as well as in the Moomins' stories or children's lives. They take different roles in our biographies. Now, writing this text in Australia, Mervi misses the feel of slippery ice and freezing wind on red cheeks, while Riikka, writing in Ireland, feels as a ski and winter expert compared with her Irish colleagues. Zsuzsa, writing in Finland, gave up her stereotypical image portraying the Arctic as populated by people who all like and can ski well and where she cannot therefore belong.

Through our poems, we have tried to give equal attention to non-human and human participants in our studies. This has allowed us to direct our focus towards a perspective that was not part of our studies at the beginning. Although the original interest of our data production has been in children's words - in what they say to us or to each other and teachers - our textual experiment has helped us not to be confined by it. We cannot make the skates and skis speak in a way that they could do if that had been our initial focus in our data production, but we can 'listen' to skates and skis and find out how they (con)fuse with children in the 'everyday'. We have moved from solely reading the field notes and interview transcripts for what meaning people made, to re-sensitize our perspective and include in our exploration when and what skates and skis mobilize in children, Moomins and ourselves in relation to 'nation-ed environments'. We have shown that skates and skis operate through touch, smell and sight. They have the ability to mobilize desire and induce intense affects. They seem to have power to prefigure the multiple and shifting ways of emerging as a child or a young person in Finland's cold winter. Yet, they do not predetermine the way childhoods (or our adulthoods) are experienced in the Arctic.

Exploring the socio-material role of skates and skis can offer opportunities to engage "more consciously" with materialities and "practices of national homemaking" (Noble, 2002, p. 61) and increase our understanding of taken-for-granted practices that tend to go unnoticed. Everyday objects 
and practices, embodied rituals or unnoticed traditions contribute to forming multiple subjectivities and 'imagined communities' (Anderson, 1991) as children 'make their home' in the Arctic (see Noble, 2002). Biographies of skates and skis, as well as children's bodily know-how and place sediments, create imaginaries and environments of home and nation. These formulations take hold of children's bodies, where their "forces and affects circulate between and are only partially apprehended by bodies inhabiting" (Merriman \& Jones, 2016) the Finnish Arctic.

I don't have to go straight home now, sometimes I get to go walking outside. Even when it's cold, sometimes. Before, I didn't know my way home but now I know two ways, road and a path through the forest. At summer, I always ride my bike. Now at winter, I get to walk with my friends. (Lilith)

\section{REFERENCES}

Aitken, Stuart C. The Ethnopoetics of Space and Transformation: Young People's Engagement, Activism and Aesthetics: Ashgate Publishing Limited, 2014.

Anderson, Ben. Encountering Affect: Capacities, Apparatuses, Conditions. New York: Routledge, 2014.

Anderson, Benedict. Imagined Communities: Reflections on the Origin and Spread of Nationalism. Rev. ed. ed. London: 1991.

Appadurai, Arjun. The Social Life of Things : Commodities in Cultural Perspective. Cambridge Cambridgeshire ; New York: Cambridge University Press, 1986.

Atkinson, Paul. The Ethnographic Imagination : Textual Constructions of Reality. London, UK: Routledge, 1990.

Brown, Lyn Mikel and Carol Gilligan. "Meeting at the Crossroads: Women's Psychology and Girls' Development." Feminism \& Psychology 3, no. 1 (1993): 11-35.

Brubaker, Rogers. "Ethnicity, Race, and Nationalism." Annual Review of Sociology 35, (2009): 21.

Brubaker, Rogers and Frederick Cooper. "Beyond 'Identity"” Theory and Society 29 (2000): 1-47.

Casey, Edward. "Between Geography and Philosophy: What does it Mean to be in the Place-World?" Annals of the Association of American Geographers 91, no. 4 (2001): 683-693.

Coffey, Amanda and Atkinson Paul Anthony. Making Sense of Qualitative Data : Complementary Research Strategies. Thousand Oaks: Sage Publications, 1996.

Edwards, Rosalind and Susie Weller. "Shifting Analytic Ontology: Using I- Poems in Qualitative Longitudinal Research." Qualitative Research 12, no. 2 (2012): 202-217.

Elerie, H. and T. Spek. "The Cultural Biography of Landscape as a Tool for Action Research in the Drentsche Aa National Landscape (Northern Netherlands)." In The Cultural Landscape and Heritage Paradox, edited by T. Blomers, T. Kars, A. Van der Valk and M. Wijnen, 83-114. Amsterdam, The Netherlands: Amsterdam University Press, 2010. 
Forsman, Liselott and Ida Hummelstedt-Djedou. "The Identity Game: Constructing and Enabling Multicultural Identities in a Finland- Swedish School Setting." British Educational Research Journal 40, no. 3 (2014): 501-522.

Fox, Jon E. "The Edges of the Nation: A Research Agenda for Uncovering the taken-for-granted Foundations of Everyday Nationhood." Nations and Nationalism 23, no. 1 (2017): 26-47.

Fox, Jon E. and Demelza Jones. "Migration, Everyday Life and the Ethnicity Bias." Ethnicities 13, no. 4 (2013): 385-400.

Gonick, Marnina and Janice Hladki. "Who are the Participants? Rethinking Representational Practices and Writing with Heterotopic Possibility in Qualitative Inquiry." International Journal of Qualitative Studies in Education 18, no. 3 (2005): 285-304.

Gilligan C, Spencer R, Weinberg MK and Bertsch T (2003) On the Listening Guide: a voice-centred relational method. In: Camic PM, Rhodes JE and Yardley L (eds) Qualitative Research in Psychology: Expanding Perspectives in Methodology and Design. Washington, DC: American Psychological Association, 157-172.

Haldrup, 2017 Souvenirs: Magical objects in everyday life. Emotion, space and society 22 (2017) 5260. http://dx.doi.org/10.1016/j.emospa.2016.12.004

Jansson, Tove. Moominland Midwinter. London, UK: Lond. : Benn, 1958.

Kopytoff, I. "The Cultural Biography of Things: Commodization as a Process." In The Social Life of Things. Commodities in a Social Perspective, edited by Arjun Appadurai, 64-91. Cambridge, UK: Cambridge University Press, 1986.

McLean Taylor, Jill, Carol Gilligan, and Amy Sullivan. Between Voice and Silence: Women and Girls, Race and Relationship. Harvard, USA: Harvard College, 1995.

Merriman, P. \& Jones, R. (2016) Nations, materialities and affects. Progress in human Geography, doi:10.1177/0309132516649453

MessageToEagle.com (2016) Ice Skates Were Used In Finland 5,000 years Ago. http://www.messagetoeagle.com/ice-skates-were-used-in-finland-5000-years-ago/

Noble, Greg. "Comfortable and Relaxed: Furnishing the Home and Nation." Continuum 16, no. 1 (2002): 53-66.

Rautio, Pauliina and Paivi Jokinen. "Children's Relations to the More-Than Human World Beyond Developmental Views." In Play and Recreation, Health and Wellbeing, edited by Bethan Gwanas, Horton John and Tracey Skelton. Singapore: Springer, 2016.

Silverman, Raymond (2015) Material biographies. History in Africa, Volume 42 (2015), pp. 375395.

Skey, Michael. (2011) National Belonging and Everyday Life: The Significance of Nationhood in an Uncertain World. Basingstoke: Palgrave.

Sparkes, Andrew C. "Novel Ethnographic Representations and the Dilemmas of Judgement." Ethnography and Education 4, no. 3 (2009): 301-319.

Sørensen, Estrid. "Human Presence: Towards a Posthumanist Approach to Experience." Subjectivity 6, no. 1 (2013): 112. 
The History and Science of Ice Skating. In All Things Considered, NPR Radio, January 26, 2008. http://www.npr.org/templates/story/story.php?storyId=18447880 